\title{
Different bacteriocin activities of Streptococcus mutans reflect distinct phylogenetic lineages
}

\author{
M. BALAKRISHNAN* + R. S. SIMMONDS*, M. KILIAN† and J. R TAGG* \\ * Department of Microbiology, University of Otago, Dunedin, New Zealand and †Department of Medical \\ Microbiology and Immunology, Bartholin Building, University of Aarhus, Aarhus C, Denmark
}

\begin{abstract}
Bacteriocins produced by mutans streptococci are known as mutacins. In this study 16 broadly active mutacin-producing Streptococcus mutans strains from New Zealand, North America and Europe were classified into four groups (A-D) on the basis of differences in their activity in deferred antagonism tests against either the homologous producer strain (to test for presence of self-immunity) or indicator strains Staphylococcus aureus 46 and Enterococcus faecium TE1. Two of the strains included in the study (UA140 and UA96) were representatives of the group I and II mutacin producer strains previously described by Caufield and co-workers. One of the New Zealand isolates of group A (S. mutans strain $N$ ) appeared to produce inhibitory activity similar to that of the group I prototype strain UA140. Four other New Zealand isolates of group B (S. mutans strains M19, M34, B34 and D14) had mutacin II-like activity. The group B mutacin producers differed from the group $A$ mutacin producers in their additional activity against Staph. aureus 46. Seven $S$. mutans strains (M46, B46, B57, M12, M28, $B 28$ and 13M) were distinguished from the group $A$ and group $B$ mutacin producers in that they inhibited $E$. faecium TE1. These were called group $C$ mutacin producers. Strains $\mathrm{H} 7$ and $\mathrm{H} 23$ resembled the group $\mathrm{C}$ strains in their action on both indicator strains TE1 and 46. However, these two strains failed to exhibit immunity to their own inhibitory products in the deferred antagonism test and were separately classified as group D mutacin producers. Phylogenetic analysis of the strains by several genotypic and phenotypic characteristics revealed that the mutacin groups were associated with distinct evolutionary lineages of $S$. mutans.
\end{abstract}

\section{Introduction}

The mutans streptococci are a group of seven oral streptococcal species that share a number of phenotypic, ecological and pathogenic attributes, among which is a high association with dental caries in man and some animal species [1-4]. The species most commonly implicated in caries development in man are Streptococcus mutans and S. sobrinus [2, 4]. One feature of the mutans streptococci is their relatively high frequency of production of bacteriocins or bacteriocin-like inhibitory substances (BLIS). Bacter-

Received 19 March 2002; accepted 2 July 2002.

Corresponding author: Professor J. R. Tagg (e-mail: john. tagg@stonebow.otago.ac.nz).

$\Varangle$ Present address: Department of Oral Sciences and Orthodontics, School of Dentistry, University of Otago, Dunedin, New Zealand. iocins are peptide or protein antibiotics that are principally bactericidal for other bacteria of the same or closely related species, and are likely to confer ecological advantage in diverse bacterial communities such as dental plaque. The term BLIS has been adopted when referring to bacteriocin-like inhibitory effects before complete characterisation of the inhibitory molecule(s) [5]. The reported incidence of BLIS production among mutans streptococci has ranged from $11 \%$ to $100 \%$ [6-14], the differences in detection frequencies probably reflecting differences in the test conditions and in the BLIS indicator strains used.

Kelstrup and Gibbons [15] initially suggested that streptococcal bacteriocins could be differentiated on the basis of their inhibitory spectra, the morphology of their inhibition zones, and their sensitivity to chloroform and various enzymes. Subsequently, Kelstrup and Funder-Nielsen [16] divided the bacteriocins of $S$. mutans into two groups according to differences in their heat sensitivity and molecular masses. One group 
was inactivated by heating at $80^{\circ} \mathrm{C}$ for $20 \mathrm{~min}$ and had molecular masses $>10000 \mathrm{Da}$. The other group comprised heat-stable molecules of $<10000 \mathrm{Da}$. However, the inhibitory agents varied considerably within both groups with respect to their sensitivity to ether, chloroform and trypsin. Bondi and co-workers [17] divided mutacin producers into five different types, according to differences in their inhibitory activity against nine oral streptococci and the sensitivity of their mutacins to heat, chloroform and protease treatment. The mutacins produced by their type II and type $\mathrm{V}$ strains were sensitive to heat $\left(80^{\circ} \mathrm{C}\right.$ for 20 min) and chloroform, whereas type III and type IV mutacins were resistant to heat and chloroform. Only the mutacins produced by type III and type $\mathrm{V}$ strains were sensitive to protease. Morency and co-workers [18] distinguished 24 groups $(\mathrm{A}-\mathrm{X})$ within a series of 86 mutacin producer strains on the basis of their activity spectra against 12 oral streptococcal indicators and their sensitivity to other mutacin producers.

Caufield and co-workers $[19,20]$ initially classified mutacin producers into groups I and II on the basis of their activity spectra and the specific immunity of the mutacin producer strains in a group to their homologous bacteriocins. It was further noted that group II strains produced inhibitory activity when grown in a liquid medium (trypticase soy broth plus yeast extract $2 \%$ ), whereas mutacin I producer strains did not. Subsequently, mutacin I [21] and mutacin II [22] have been purified and shown to belong to the class of bacteriocins known as the lantibiotics. These researchers have also isolated a lantibiotic called mutacin III from S. mutans strain UA787 [23]. More recently, this group has reported that the group I S. mutans strain UA140 produces, in addition to mutacin I, a twocomponent non-lantibiotic bacteriocin named mutacin IV [24]. Interestingly, the NlmB component of mutacin IV shares partial homology with mutacin $N$ [25].

A number of years ago a bacteriocin typing scheme first developed in this laboratory [26] was applied to the study of BLIS production among mutans streptococci [9]. It was found that $39 \%$ of 18 culture collection strains and $69 \%$ of 35 fresh isolates produced inhibitory activity with 7 and 13 different patterns of inhibitory activity (P-types), respectively, being distinguished against 9 standard indicator strains. Three $(9.7 \%)$ of the 31 mutacin producers gave particularly strong (P-type 777) activity against all 9 standard indicators.

In the present study, $16 \mathrm{~S}$. mutans strains displaying Ptype 777 inhibitory activity have been arranged into four different groups on the basis of their spectra of inhibitory activity and their BLIS immunity specificities. The potential relatedness of this grouping to phylogenetic lineages of $S$. mutans as revealed by analyses of genotypic and phenotypic characteristics was also evaluated.

\section{Materials and methods}

\section{Bacterial strains}

The 16 BLIS-producing mutans streptococci examined in depth were $S$. mutans strains UA96, UA140, B57, M12, M19, M28, B28, M34, B34, M46, B46, N, 13M, D14, H7 and H23. S. mutans strains D14, H7 [27] and H23 were from our laboratory culture collection. $S$. mutans strains UA140 (producer of mutacin I) and UA96 (producer of mutacin II) were provided by P. W. Caufield (Department of Oral Biology, School of Dentistry, University of Alabama, USA) and S. mutans strain 13M [28] was from A. H. Rogers (Department of Oral Biology, University of Adelaide, Australia). The other BLIS-producing $S$. mutans strains were isolated from plaque samples from dental students aged 20-23 years in Dunedin, New Zealand. The pairs of strains (M28 and B28; M34 and B34; M46 and B46) were independently derived isolates from subjects 28,34 and 46. Non-BLIS-producing S. mutans strains were from the following sources: S. Hamada (strain OMZ175 originally isolated in Switzerland [29]), National Institute of Health, Tokyo, Japan; G. Colman (strains UTB1 and UTB2), Central Public Health Laboratory, London; D. B. Clewell (strain LM7), University of Michigan, Ann Abor, MI, USA. All other non-BLISproducing $S$. mutans strains (G26-41, G26-47, H8-P, K1Ye, G31, G31P, H12-P, D1, H10, H13, D16 and D2) were isolated in New Zealand and were from our laboratory culture collection. The strain pairs (G26-41 and G26-47; G31 and G31P) were from plaque specimens taken over intervals of 2 and 1 years, respectively, from subjects 26 and 31 . The identity of the test strains was determined by their colony morphology on TYCSB medium [30], and by testing for mannitol, sorbitol, raffinose, amygdalin and melibiose fermentation, arginine and aesculin hydrolysis, and production of extracellullar glucan [31,32]. Further confirmation of species identity was obtained by using BIOLOG system panels (Biology Inc., Hayward, CA, USA) for gram-positive bacteria. The identity of selected strains was further confirmed by partial sequencing of $16 \mathrm{~S}$ rRNA genes as described previously [33]. The sequences of c. 450 nucleotides were compared with that of the type strain of $S$. mutans by the BLAST algorithm available at the National Center for Biotechnology Information (NCBI; Bethesda, MD, USA). The nine standard indicators of streptococcal BLIS (strains I1-I9) have been described previously [26]. The bacterial strains used as indicators to define the spectra of inhibitory activity of the mutacin producers were from the Microbiology Department culture collection.

\section{Deferred antagonism test of BLIS activity}

The spectrum of inhibitory activity of each BLIS producer strain was established by use of a deferred antagonism test, essentially as described by Tagg and Bannister [26]. Briefly a 1-cm wide diametric streak 
culture of each producer strain was inoculated on to TSYCa (Trypticase soy broth; Baltimore Biological Laboratories, Becton Dickinson, USA) plus yeast extract (Difco) 2\%, Davis agar (Davis Gelatine, Christchurch, New Zealand) $1.5 \%, \mathrm{CaCO}_{3}$ (BDH, Poole, Dorset) $0.25 \%$ ) agar plates and incubated in an atmosphere of $\mathrm{CO}_{2} 5 \%$ in air for $24 \mathrm{~h}$ at $37^{\circ} \mathrm{C}$. After removing the macroscopic cell growth with a glass slide, residual cells on the agar surface were killed by exposure to chloroform vapour for $30 \mathrm{~min}$. The agar surface was then aired for $30 \mathrm{~min}$ and the indicator strains were inoculated from 18-h THB cultures across the line of the original streak culture with cotton swabs. After incubation for $18 \mathrm{~h}$ in $\mathrm{CO}_{2} 5 \%$ in air at $37^{\circ} \mathrm{C}$ the extent of inhibition of each indicator strain was recorded.

The 16 BLIS producer strains used in this study were strongly inhibitory to all 9 standard indicator strains used in this laboratory for streptococcal BLIS fingerprinting [26]. Staphylococcus aureus strain 46 and Enterococcus faecium strain TE1 were found to be especially useful in distinguishing between the different groups of BLIS producers when used as indicators. In determining the extended inhibitory spectra of these strains, 29 mutans streptococci ( $S$. mutans, 18 strains; $S$. sobrinus, 5 strains; $S$. rattus, 4 strains; $S$. cricetus, 2 strains), 18 oral streptococci ( $S$. sanguis, 3 strains; $S$. gordonii, 3 strains; $S$. oralis, 4 strains; S. mitis, 2 strains; $S$. anginosus, 1 strain; $S$. salivarius, 5 strains), 8 enterococci and 8 Staph. aureus were used as indicators. The mutacin I and mutacin II producer strains ( $S$. mutans UA140 and UA96, respectively) provided by Caufield and the four BLIS producers used as prototypes of mutacin groups $\mathrm{A}-\mathrm{D}$ in the present study were tested against $25 \mathrm{~S}$. pyogenes, 15 lactobacilli and 13 Escherichia coli strains.

\section{Heat stability of mutacins}

The heat stability of the inhibitory agents was tested initially by heating freshly grown deferred antagonism streak cultures (on TSYCa medium) of the producer strains at $80^{\circ} \mathrm{C}$ for $30 \mathrm{~min}$. After heating, the visible growth of the test strain was removed and the surface of the plate was exposed to chloroform vapour and aired as described above. The nine standard indicator strains were then streaked across the line of the producer growth and the plates were incubated aerobically for $18 \mathrm{~h}$. After incubation, the extent of interference with the indicator growth on the heated plates was compared with that given by the corresponding unheated streak culture of each test strain.

\section{Multilocus enzyme electrophoresis}

Bacterial lysates for multilocus enzyme electrophoresis (MLEE) analysis were prepared and stored as described by Helmig et al. [34]. The lysates were electrophoresed in starch gels and selectively stained for activity of each of eight metabolic enzymes as described by Selander et al. [35]. The enzymes assayed were: adenylate kinase (ADK), carbamylate kinase (CDK), glutamate dehydrogenase 2 (GD2), hexokinase (HEX), leucylglycylglycine peptidase (LGG), nucleoside phosphorylase (NSP), phosphoglucose isomerase (PGI) and phosphoglucomutase (PGM). Buffer system A (Triscitrate, $\mathrm{pH}$ 8.0) was used for LGG, GD2, PGM, ADK, CDK, HEX; buffer system D (lithium hydroxide buffer system; gel buffer, $\mathrm{pH} 8.3$; tray buffer, $\mathrm{pH}$ 8.1) for NSP and PGI. Each electrophoretic mobility was assigned a number that is equated with a distinct allele in the structural gene of the respective enzyme gene locus.

\section{Haemolytic activity and pigment production}

The haemolytic activity of both mutacin producers and non-producers was tested with double-layer agar plates consisting of a base layer of saline agar $(\mathrm{NaCl} 0.85 \%$ plus Davis agar 1.5\%) and a top layer of Columbia agar base (CAB; Gibco BRL, Life Technologies, Paisley, Scotland) containing human blood $5 \% \mathrm{v} / \mathrm{v}$ [9]. Test colonies were inoculated into these plates with sterile tooth picks and incubated in an atmosphere of $\mathrm{CO}_{2} 5 \%$ in air at $37^{\circ} \mathrm{C}$ for $48 \mathrm{~h}$. Pigment production was assessed by visual examination of colonies for yellow pigmentation after anaerobic incubation for 2 days on TYCSB medium [30].

\section{Plasmid detection}

Total DNA from each BLIS-producing strain was extracted by the method of Ushiro and co-workers [36], the DNA was electrophoresed in an agarose $1 \%$ $\mathrm{w} / \mathrm{v}$ gel and the gel was stained with ethidium bromide and examined under UV light to visualise the presence of plasmid DNA. Plasmid-containing S. mutans strains UA96 and UA140 were used as controls.

\section{Cluster analysis}

Cluster analysis of the strains was based on electrophoretic mobility assignments of the eight enzymes determined by MLEE, the results of aesculin hydrolysis, amygdalin fermentation, and $\beta$-haemolysis. A distance matrix was constructed with the ETMEGA program developed by T. S. Whittam (www.foodsafe. msu.edu/whittam/\#Programs) and the phylogenetic tree was made by the minimum evolution algorithm, which is part of the MEGA version 2.1 software of Kumar et al. [37].

\section{Results}

\section{Speciation of mutans streptococcus strains}

All the BLIS-producing strains were identified as $S$. mutans. They fermented mannitol, sorbitol, raffinose and melibiose, and produced extracellular glucans from sucrose. Variations were observed in their ability to 
ferment amygdalin, hydrolyse aesculin and induce $\beta$ haemolysis on blood agar (see below). Partial 16S rRNA gene sequences of two representative strains of each of the observed biochemical profiles showed $99 \%$ homology with the $S$. mutans type strain and confirmed their identity.

\section{Differentiation of BLIS-producing mutans streptococci}

The 16 P-type 777 mutans streptococci were assigned to four distinct groups on the basis of the tests conducted in this study (Table 1). The group A, B and C strains appeared to be insensitive to their own inhibitory products and to the BLIS activities of every other strain within that same group. By contrast, the strains in group D produced BLIS activities that were inhibitory to the homologous producer strain when this was used as an indicator in the deferred antagonism test. Staph. aureus 46 and E. faecium TE1 were sensitive to the inhibitory products of group $\mathrm{C}$ and group D strains. Group B strains were active only on Staph. aureus 46. The group A strains did not act on either of these indicators. The inhibitory activities of all 16 strains appeared unaffected by heating at $80^{\circ} \mathrm{C}$ for $30 \mathrm{~min}$ (Table 1).

Further testing of the activity spectra of the four prototype producer strains (A, N; B, M19; C, M46; D, H7) indicated that they inhibited all 18 miscellaneous oral streptococcal strains tested. They also inhibited 29 mutans streptococci (Table 2). The group C and D prototype strains inhibited all the tested Staph. aureus and enterococcal indicators. By contrast the group A prototype strain did not inhibit any of the strains of Staph. aureus or enterococci. The group B prototype producer inhibited just one (strain 46) of eight Staph. aureus indicators tested and none of the enterococci. The group $\mathrm{C}$ and $\mathrm{D}$ prototype strains inhibited all 15 lactobacilli, but the group A and B prototype producer strains appeared to be less effective, inhibiting only one and eight of the lactobacilli, respectively. None of the prototype strains inhibited any of the Esch. coli tested.

The only BLIS-producing strains found to contain plasmids $(c .5 .6 \mathrm{~kb})$ were the prototype mutacin I and mutacin II producers (strains UA140 and UA96).

\section{Cluster analysis of the different groups of BLIS producers}

To evaluate if the different BLIS activity profiles were associated with particular evolutionary lineages of $S$. mutans, cluster analysis was performed on the basis of MLEE data, and the ability to hydrolyse aesculin, ferment amygdalin and effect $\beta$-haemolysis. The resulting phylogenetic tree and the association between the clustering of the strains, their BLIS activity profiles and selected phenotypic traits are shown in Fig. 1. All five group B strains clustered identically by all characteristics and were distinct from all other strains. Likewise, all group $\mathrm{C}$ strains clustered together in the

Table 1. Characteristics of different BLIS-producing groups of S. mutans

\begin{tabular}{|c|c|c|c|c|c|c|c|}
\hline \multirow[b]{2}{*}{$\begin{array}{l}\text { Group and strain } \\
\text { designation }\end{array}$} & \multirow[b]{2}{*}{ P-type } & \multicolumn{4}{|c|}{ Inhibitory activity against } & \multirow[b]{2}{*}{$\begin{array}{l}\text { Heat* } \\
\text { stability }\end{array}$} & \multirow[b]{2}{*}{ Plasmid } \\
\hline & & $\begin{array}{l}\text { other } \\
\text { groups }\end{array}$ & self & $46^{\dagger}$ & $\mathrm{TE} 1^{*}$ & & \\
\hline \multicolumn{8}{|l|}{ Group A } \\
\hline $\mathrm{N}^{\S}$ & 777 & + & - & - & - & + & - \\
\hline $\begin{array}{l}\text { UA140 (mutacin I } \\
\text { producer) }\end{array}$ & 777 & + & - & - & - & + & + \\
\hline \multicolumn{8}{|l|}{ Group B } \\
\hline M19§ & 777 & + & - & + & - & + & - \\
\hline M34 & 777 & + & - & + & - & + & - \\
\hline B34 & 777 & + & - & + & - & + & - \\
\hline D14 & 777 & + & - & + & - & + & - \\
\hline $\begin{array}{l}\text { UA96 (mutacin II } \\
\text { producer) }\end{array}$ & 777 & + & - & + & - & + & + \\
\hline \multicolumn{8}{|l|}{ Group C } \\
\hline $\mathrm{M} 46^{\S}$ & 777 & + & - & + & + & + & - \\
\hline B46 & 777 & + & - & + & + & + & - \\
\hline B57 & 777 & + & - & + & + & + & - \\
\hline M12 & 777 & + & - & + & + & + & - \\
\hline M28 & 777 & + & - & + & + & + & - \\
\hline B28 & 777 & + & - & + & + & + & - \\
\hline $13 \mathrm{M}$ & 777 & + & - & + & + & + & - \\
\hline \multicolumn{8}{|l|}{ Group D } \\
\hline $\mathrm{H} 7^{\S}$ & 777 & + & + & + & + & + & - \\
\hline $\mathrm{H} 23$ & 777 & + & + & + & + & + & - \\
\hline
\end{tabular}


Table 2. Inhibitory activities of prototype mutacin-producing strains against test strains of various bacterial species

\begin{tabular}{lccccc}
\hline & & \multicolumn{3}{c}{$\begin{array}{c}\text { Number of indicator strains sensitive to BLIS produced } \\
\text { by prototype strain of group }\end{array}$} \\
\cline { 2 - 6 } Indicator strain & $\begin{array}{c}\text { Number } \\
\text { tested }\end{array}$ & $\mathrm{A}$ & $\mathrm{B}$ & $\mathrm{C}$ & $\mathrm{D}$ \\
\hline Mutans streptococci & $29^{*}$ & 29 & 29 & 29 & 29 \\
Oral streptococci & $18^{\dagger}$ & 18 & 18 & 18 & 18 \\
S. pyogenes & 25 & 25 & 25 & 25 & 25 \\
Enterococcus spp. & 8 & 0 & 0 & 8 & 8 \\
Lactobacillus spp. & 15 & 1 & 8 & 15 & 15 \\
Staph. aureus & 8 & 0 & 1 & 8 & 8 \\
Esch. coli & 13 & 0 & 0 & 0 & 0 \\
\hline
\end{tabular}

*S. mutans, 18 strains; S. sobrinus, 5 strains; S. rattus, 4 strains; S. cricetus, 2 strains.

${ }^{\dagger} S$. sanguis, 3 strains; $S$. gordonii, 3 strains; $S$. oralis, 4 strains; $S$. mitis, 2 strains; $S$. anginosus, 1 strain; S. salivarius, 5 strains.

phylogenetic tree. The two group D strains clustered together with two non-producer strains. The phylogenetic analysis shows that non-producer strains otherwise formed two major clusters. The two group A strains were genetically unrelated.

\section{Discussion}

Various researchers have reported that the bacteriocins produced by mutans streptococci are strongly inhibitory to other mutans streptococci as well as to strains of many other Streptococcus species [7, 10, 38-40]. The finding that all 16 of the P-type 777 mutans streptococcal BLIS producers investigated in the present study had widespread activity against other strains of mutans streptococci is in full agreement with these observations. By contrast, Weerkamp and co-workers [41] did not observe inhibition by $S$. mutans of other $S$. mutans indicator strains, but they did find that the $S$. mutans producers were inhibitory to $S$. salivarius, $S$. mitis and $S$. sanguis. The finding in the present study that group C and D strains inhibited enterococci and Staph. aureus is also not unprecedented. Inhibitory activity of mutans streptococci against enterococci [7, 39, 42] and Staph. aureus [7, 38,39 ] has been reported in other studies.

To date, the use of deferred antagonism tests to group mutans streptococci on the basis of their bacteriocin production has had only limited success, largely due to lack of reproducibility of the technique. The very sensitivity of the deferred antagonism test means that it is inherently susceptible to interference from nonbacteriocin agents such as secondary metabolities and lytic bacteriophages [5]. The impact of these on inhibition patterns needs to be carefully controlled. Consideration of the inhibitory activity of bacteriocin producer strains against themselves in deferred antagonism tests is particularly discriminating. It is generally accepted that all bacteriocin producers must protect themselves from the lethal action of their own product by expression of specific immunity genes [43]. Thus, strains expressing bacteriocin genes generally exhibit immunity to the homologous bacteriocin and remain sensitive to heterologous bacteriocins. This characteristic has been used by others to aid differentiation of the bacteriocins produced by mutans streptococci [19]. By including strains known to produce the previously documented mutacin I (UA140) and mutacin II (UA96) in this study, direct comparison of our current BLIS groupings with the mutacin groupings reported by Caufield and co-workers was made possible. The activity spectrum and immunity characteristics of strains UA140 and UA96 were identical to those of strains categorised in the present study as group A and $\mathrm{B}$ strains respectively. In contrast, the group D strains failed to exhibit immunity to self under the current test conditions. Inhibition of self by mutans streptococci $[7,39,44]$ and by other streptococci [45] has been reported elsewhere. Delisle [46] reported that bacteriocin production by $S$. rattus strain BHT in APT-yeast broth occurred after the culture entered stationary growth phase and suggested that bacteriocin synthesis may be lethal to the producer cell.

Group B and some non-BLIS-producing strains were haemolytic on human blood agar. Crooks and coworkers [9] previously reported that strain D14 (group B) was haemolytic on human blood agar. Although not fully characterised, the association of bacteriocin production and haemolytic activity has been reported previously in some S. mutans [9] and S. salivarius [47]. The production of a protein that combines bacteriocin and haemolytic activity (bacteriocin/haemolysin) by $E$. faecalis strains is now well documented [48]. Caufield and co-workers [49] noted that both mutacin I- and mutacin II-producing strains were pigmented, but did not comment upon any possible association between mutacin production and haemolysis. In the present study, all group B strains were pigmented, which further points to a strong association between production of the lantibiotic mutacin II and strain pigmentation.

Initially, Caufield and co-workers $[19,20]$ proposed that 


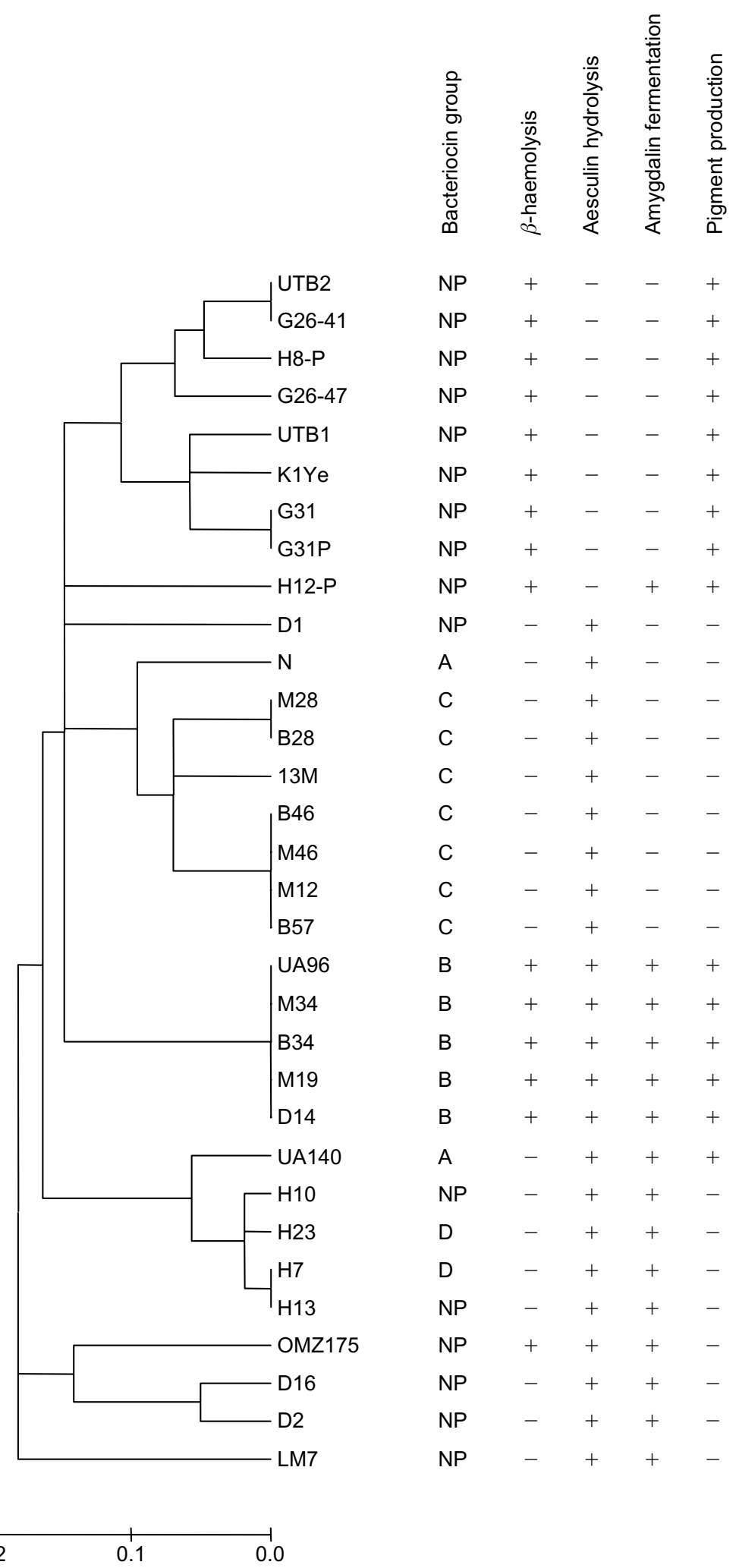

Fig. 1. Dendrogram illustrating the phylogenetic lineages of bacteriocin-producing and non-producing $S$. mutans. NP, nonproducer.

5.6-kb plasmids present in strains producing mutacin I and mutacin II might carry genes encoding the production of these mutacins. However, evidence was presented later that suggested that mutacin production by these strains is chromosomally encoded $[49,50]$. Evidence for the chromosomal location of the mutacin- encoding gene was obtained when a mutacin-negative derivative of strain UA96 was shown to result from the insertion of transposon Tn916 into chromosomal DNA [50]. Later the chromosomal location of mutacin I [21], mutacin II [51] and mutacin III [23] structural genes was confirmed by cloning and sequencing. More 
recently Qi and co-workers [24] reported that the two components of mutacin IV produced by strain UA140 are encoded by the chromosomally located $n \operatorname{lm} A$ and $n \operatorname{lm} B$ genes. In the present study, no spontaneous loss of BLIS-producing ability was observed for any of the mutacin producers and none of the strains (except UA96 and UA140) appeared to harbour plasmids. This strongly suggests that a chromosomal location for genes associated with mutacin production is the rule rather than the exception.

The population genetic analysis performed on the $S$. mutans strains revealed a strong association between the strains in groups $\mathrm{B}$ and $\mathrm{C}$ and distinct evolutionary lineages. Conceivably, this association is a reflection of linkage disequilibrium of alleles and thus a clonal population structure. The coupling of bacteriocin activity patterns with particular alleles of housekeeping enzyme genes and selected phenotypic traits further supports the conclusion that the bacteriocin genes are chomosomally located rather than on mobile genetic elements. It is of interest that the two genetically unrelated group A strains (UA140 and N) appear to produce similar bacteriocin activities (mutacin IV and mutacin $\mathrm{N}$ ). The similarity of these bacteriocin determinants indicates that these genes may have been horizontally transferred. Likewise, the finding that two of four genetically closely related strains of group D had bacteriocin activity while the two remaining strains were negative may suggest that mutations have led to loss of inhibitory activity.

Bacteriocins produced by each prototype strain have now been isolated and their preliminary characterisation confirms the existence of at least four distinct mutacins [52]. The $\mathrm{N}$-terminal sequence of mutacin $\mathrm{N}$ (group A) indicates that this peptide does not contain lanthionine or $\beta$-methyl lanthionine and that it has a strong match to a putative sugar-phosophotransferase enzyme from Acholeplasma florum [25]. One component of the non-lantibiotic bacteriocin mutacin IV [24] purified from strain UA140 (group A in the present study) shows a high degree of similarity to mutacin $\mathrm{N}$ despite the fact that the producing strains appear to be phylogenetically distinct. The N-terminal amino acid sequence of mutacin M19 (group B) [52] is identical to that of the lantibiotic mutacin II [22]. N-Terminal sequencing of mutacin M46 (group C) and mutacin H7 (group D) was blocked; however, amino acid composition analysis indicates that neither of these mutacins contains lanthionine or $\beta$-methyl lanthionine [52].

In the present study only those strains producing strong BLIS activity against a broad spectrum of indicator strains were selected for detailed investigation. The use of only a single nutrient medium (TSYCa) and one set of incubation conditions $\left(\mathrm{CO}_{2} 5 \%\right.$ in air at $\left.37^{\circ} \mathrm{C}\right)$ also will have limited the consideration to mutacins produced well under these particular culture conditions. Local strains producing BLIS activities with character- istics corresponding to those of mutacins I and II (originally proposed by Caufield and co-workers $[19,20])$ were detected. Furthermore, strains of $S$. mutans were identified that appeared to produce two previously uncharacterised types of mutacin activities (groups C and D). Biochemical and genetic characterisation of representative prototype producer strains from each of these groups supported the conclusion that each mutacin group was fundamentally different.

This study was supported by grants from the New Zealand Dental Research Foundation and the Health Research Council of New Zealand.

\section{References}

1. Emilson C-G, Krasse B. Support for and implications of the specific plaque hypothesis. Scand J Dent Res 1985; 93: 96-104.

2. Loesche WJ. Role of Streptococcus mutans in human dental decay. Microbiol Rev 1986; 50: 353-380.

3. Bratthall D. The global epidemiology of mutans streptococci. In: Johnson NW (ed) Dental caries. Risk markers for oral diseases, vol I. Cambridge, Cambridge University Press. 1991: 287-312.

4. Balakrishnan M, Simmonds RS, Tagg JR. Dental caries is a preventable infectious disease. Aust Dent $J$ 2000; 45: 235-245.

5. Tagg JR, Dajani AS, Wannamaker LW. Bacteriocin of grampositive bacteria. Bacteriol Rev 1976; 40: 722-756.

6. Berkowitz RJ, Jordan HV. Similarity of bacteriocins of Streptococcus mutans from mother and infant. Arch Oral Biol 1975; 20: $725-730$.

7. Rogers AH. Bactericinogeny and the properties of some bacteriocins of Streptococcus mutans. Arch Oral Biol 1976; 21: $99-104$.

8. Berkowitz RJ, Jones P. Mouth-to-mouth transmission of the bacterium Streptococcus mutans between mother and child. Arch Oral Biol 1985; 30: 377-379.

9. Crooks M, James SM, Tagg JR. Relationship of bacteriocinlike inhibitor production to the pigmentation and hemolytic activity of mutans streptococci. Zentralbl Bakteriol Mikrobiol Hyg A 1987; 263: 541-547.

10. Fabio U, Bondi M, Manicardi G, Messi P, Neglia R. Production of bacteriocin-like substances by human oral streptococci. Microbiologica 1987; 10: 363-370.

11. Ikeda T, Kurita T, Hirasawa M. Suppression of Streptococcus sobrinus $6715(\mathrm{~g})$ in plaques by Streptococcus mutans 32K (c). J Oral Pathol 1988; 17: 471-474.

12. Alaluusua S, Takei T, Ooshima T, Hamada S. Mutacin activity of strains isolated from children with varying levels of mutans streptococci and caries. Arch Oral Biol 1991; 36: 251-255.

13. Azevedo RVP, Zelante F. Streptococci of the mutans group: confirmation of intrafamilial transmission by mutacin typing. Braz Dent J 1994; 5: 27-34.

14. Grönroos L, Saarela M, Mättö J, Tanner-Salo U, Vuorela A, Alaluusua S. Mutacin production by Streptococcus mutans may promote transmission of bacteria from mother to child. Infect Immun 1998; 66: 2595-2600.

15. Kelstrup J, Gibbons RJ. Bacteriocins from human and rodent streptococci. Arch Oral Biol 1969; 14: 251-258.

16. Kelstrup J, Funder-Nielsen TD. Synthesis of bacteriocins in liquid cultures of Streptococcus mutans. J Biol Buccale 1977; 5: 99-106.

17. Bondi M, Neglia RG, Messi P, Manicardi G, Fabio U. Streptococcus mutans: classification in bacteriocin-types. Microbiologica 1991; 14: 223-228.

18. Morency H, Trahan L, Lavoie MC. Preliminary grouping of mutacins. Can J Microbiol 1995; 41: 826-831.

19. Caufield PW, Childers NK, Allen DN, Hansen JB. Distinct bacteriocin groups correlate with different groups of Streptococcus mutans plasmids. Infect Immun 1985; 48: 51-56.

20. Caufield PW, Childers NK, Allen DN et al. Plasmids in Streptococcus mutans: usefulness as epidemiological markers and association with mutacins. In: Hamada S, Michalek SM, 
Kiyono H, Menaker L, McGhee JR (eds) Molecular microbiology and immunobiology of Streptococcus mutans. Amsterdam, Elsevier Science Publishers. 1986: 217-223.

21. Qi F, Chen P, Caufield PW. Purification and biochemical characterization of mutacin I from the group I strain of Streptococcus mutans, $\mathrm{CH} 43$, and genetic analysis of the mutacin I biosynthesis genes. Appl Environ Microbiol 2000; 66: $3221-3229$.

22. Novák J, Caufield PW, Miller EJ. Isolation and biochemical characterization of a novel lantibiotic mutacin from Streptococcus mutans. J Bacteriol 1994; 176: 4316-4320.

23. Qi F, Chen P, Caufield PW. Purification of mutacin III from group III Streptococcus mutans UA787 and genetic analyses of mutacin III biosynthesis genes. Appl Environ Microbiol 1999; 65: 3880-3887.

24. Qi F, Chen P, Caufield PW. The group I strain of Streptococcus mutans, UA140, produces both the lantibiotic mutacin I and a nonlantibiotic bacteriocin, mutacin IV. Appl Environ Microbiol 2001; 67: 15-21.

25. Balakrishnan M, Simmonds RS, Carne A, Tagg JR. Streptococcus mutans strain $\mathrm{N}$ produces a novel low molecular mass non-lantibiotic bacteriocin. FEMS Microbiol Lett 2000; 183 $165-169$.

26. Tagg JR, Bannister LV. 'Fingerprinting' $\beta$-haemolytic streptococci by their production of and sensitivity to bacteriocine-like inhibitors. J Med Microbiol 1979; 12: 397-411.

27. Balakrishnan M, Simmonds RS, Tagg JR. Diverse activity spectra of bacteriocin-like inhibitory substances having activity against mutans streptococci. Caries Res 2001; 35: 75-80.

28. Rogers $\mathrm{AH}$. Bacteriocin patterns of strains belonging to various serotypes of Streptococcus mutans. Arch Oral Biol 1976; 21 243-249.

29. Guggenheim B. Streptococci of dental plaques. Caries Res 1968; 2: $147-163$.

30. van Palenstein Helderman WH, Ijsseldijk M, Huis in ' $T$ Veld JHJ. A selective medium for the two major subgroups of the bacterium Streptococcus mutans isolated from human dental plaque and saliva. Arch Oral Biol 1983; 28: 599-603.

31. Shklair IL, Keene HJ. A biochemical scheme for the separation of the five varieties of Streptococcus mutans. Arch Oral Biol 1974; 19: 1079-1081.

32. Kilian M, Mikkelsen L, Henrichsen J. Taxonomic study of viridans streptococci: description of Streptococcus gordonii sp.nov. and emended descriptions of Streptococcus sanguis (White and Niven 1946), Streptococcus oralis (Bridge and Senath 1982) and Streptococcus mitis (Andrewes and Horder 1906). Int J Syst Bacteriol 1989; 39: 471-484.

33. Mikkelsen L, Theilade E, Poulsen K. Abiotrophia species in early dental plaque. Oral Microbiol Immunol 2000; 15: 263-268.

34. Helmig R, Uldbjerg N, Boris J, Kilian M. Clonal analysis of Streptococcus agalactiae isolated from infants with neonatal sepsis or meningitis and their mothers and from healthy pregnant women. J Infect Dis 1993; 168: 904-909.

35. Selander RK, Caugant DA, Ochman H, Musser JM, Gilmour MN, Whittam TS. Methods of multilocus enzyme electrophoresis for bacterial population genetics and systematics. Appl
Environ Microbiol 1986; 51: 873-884.

36. Ushiro I, Lumb SM, Aduse-Opoku J, Ferretti JJ, Russell RRB. Chromosomal deletions in melibiose-negative isolates of Streptococcus mutans. J Dent Res 1991; 70: 1422-1426.

37. Kumar S, Tamura K, Jakobsen IB, Nei M. Molecular Evolutionary Genetics Analysis software. MEGA2. Tempe, AZ, Arizona State University. 2001.

38. Hillman JD, Johnson KP, Yaphe BI. Isolation of a Streptococcus mutans strain producing a novel bacteriocin. Infect Immun 1984; 44: 141-144.

39. Parrot M, Caufield PW, Lavoie MC. Preliminary characterization of four bacteriocins from Streptococcus mutans. Can J Microbiol 1990; 36: 123-130.

40. Van Loveren C, Buijs JF, ten Cate JM. Similarity of bacteriocin activity profiles of mutans streptococci within the family when the children acquire the strains after the age of 5 . Caries Res 2000; 34: 481-485.

41. Weerkamp A, Vogels GD, Skotnicki M. Antagonistic substances produced by streptococci from human dental plaque and their significance in plaque ecology. Caries Res 1977; 11: $245-256$.

42. Hamada S, Ooshima T. Inhibitory spectrum of a bacteriocinlike substance (mutacin) produced by some strains of Streptococcus mutans. J Dent Res 1975; 54: 140-145.

43. Jack RW, Tagg JR, Ray B. Bacteriocins of gram-positive bacteria. Microbiol Rev 1995; 59: 171-200.

44. Delisle AL. Properties of mutacin b, an antibacterial substance produced by Streptococcus mutans strain BHT. Microbios 1986 46: $21-28$.

45. Tagg JR, Russell C. Bacteriocin production by Streptococcus salivarius strain P. Can J Microbiol 1981; 27: 918-923.

46. Delisle AL. Production of bacteriocins in a liquid medium by Streptococcus mutans. Antimicrob Agents Chemother 1975; 8: 707-712.

47. Tompkins GR, Tagg JR. Bacteriocin-like inhibitory activity associated with beta-hemolytic strains of Streptococcus salivarius. J Dent Res 1987; 66: 1321-1325.

48. Ike Y, Clewell DB, Segarra RA, Gilmore MS. Genetic analysis of the pAD1 hemolysin/bacteriocin determinant in Enterococcus faecalis: Tn917 insertional mutagenesis and cloning. J Bacteriol 1990; 172: 155-163.

49. Caufield PW, Shah G, Hollingshead SK, Parrot M, Lavoie MC Evidence that mutacin II production is not mediated by a 5.6-kb plasmid in Streptococcus mutans. Plasmid 1990; 24: $110-118$.

50. Caufield PW, Shah GR, Hollingshead SK. Use of transposon Tn916 to inactivate and isolate a mutacin-associated gene from Streptococcus mutans. Infect Immun 1990; 58: 4126-4135.

51. Woodruff WA, Novák J, Caufield PW. Sequence analysis of mutA and mutM genes involved in the biosynthesis of the lantibiotic mutacin II in Streptococcus mutans. Gene 1998; 206: $37-43$.

52. Balakrishnan M. Purification and characterisation of mutacins produced by different clusters of inhibitory mutans streptococci. PhD thesis, University of Otago, Dunedin, New Zealand, 1998. 